Original article

\title{
Increased expression of interferon-inducible genes in macaque lung tissues during simian immunodeficiency virus infection
}

\author{
Todd M Schaefer ${ }^{a, 1,2}$, Craig L. Fuller ${ }^{a, 2,3}$, Shrabani Basu ${ }^{a}$, Beth A. Fallert ${ }^{\text {a }}$, \\ Sandra L. Poveda ${ }^{\mathrm{a}, 4}$, Sonali K. Sanghavi ${ }^{\mathrm{a}, 5}$, Yang-Kyu Choi ${ }^{\mathrm{a}, \mathrm{b}}$, \\ Denise E. Kirschner ${ }^{c}$, Eleanor Feingold ${ }^{\text {d,e }}$, Todd A. Reinhart ${ }^{a, *}$ \\ a Department of Infectious Diseases and Microbiology, Graduate School of Public Health, \\ University of Pittsburgh, 130 DeSoto St., Pittsburgh, PA 15261, USA \\ ${ }^{\mathrm{b}}$ Department of Laboratory Animal Medicine, College of Veterinary Medicine, Konkuk University, \\ 1 Hwayang-dong, Gwanjin-gu, Seoul 143-701, South Korea \\ c Department of Microbiology and Immunology, University of Michigan Medical School, Ann Arbor, MI 48109-0260, USA \\ d Department of Human Genetics, Graduate School of Public Health, University of Pittsburgh, 130 DeSoto St., Pittsburgh, PA 15261, USA \\ e Department of Biostatistics, Graduate School of Public Health, University of Pittsburgh, 130 DeSoto St., Pittsburgh, PA 15261, USA
}

Received 10 November 2005; accepted 20 February 2006

Available online 2 May 2006

\begin{abstract}
Pulmonary infections and dysfunction are frequent outcomes during the development of immunodeficiency associated with human immunodeficiency virus type 1 (HIV-1) infection, and obtaining a better understanding of the immunologic changes that occur in lungs following HIV-1 infection will provide a foundation for the development of further intervention strategies. We sought here to identify changes in the pulmonary immune environment that arise during simian immunodeficiency virus (SIV) infection of rhesus macaques, which serves as an excellent model system for HIV-1 infection and disease. To examine the gene expression profiles of macaque lung tissues following infection with the pathogenic SIV/DeltaB670 isolate, we performed cDNA microarray hybridizations with lung total RNAs using two commercially available cDNA arrays and a custom-fabricated, immunologically focused macaque cDNA microarray. In situ hybridization and real-time RT-PCR were performed to provide additional analyses of gene expression. Among the genes exhibiting the highest level of induction in lung tissues were the IFN- $\gamma$-inducible chemokines, CXCL10/IP-10 and CXCL9/Mig. In situ hybridization and real-time RT-PCR strongly supported these findings. Correlation analyses revealed that the levels of expression of IFN- $\gamma$, CXCL9/Mig, and CXCL10/IP-10 mRNAs were all strongly positively correlated, and that CXCL10/IP-10 mRNA and Pneumocystis carinii rRNA were positively correlated. Taken together, these findings demonstrate that inflammatory chemokines are among the most differentially expressed mRNAs in macaque lung tissues during systemic SIV infection of rhesus macaques, and provide insight into the complicated events occurring in the lung tissues during HIV-1 infection in humans.
\end{abstract}

(C) 2006 Elsevier SAS. All rights reserved.

Keywords: SIV; HIV; Interferon; Lung; Chemokine

\footnotetext{
* Corresponding author. Tel.: +1 412648 2341; fax +1 4126244873.

E-mail address: reinhar@pitt.edu (T.A. Reinhart).

${ }^{1}$ Present address: Department of Physiology. Dartmouth Medical School, 1 Medical Center Drive, Lebanon, NH 03756, USA.

${ }^{2}$ Contributed equally to this work.

${ }^{3}$ Present address: School of Health Sciences, Eastern Michigan University, 322 Marshall Building, Ypsilanti, MI 48197, USA.

${ }^{4}$ Present address: Department of Otolaryngology, University of Pittsburgh School of Medicine, Pittsburgh, PA 15213, USA.

${ }^{5}$ Present address: Laboratory of Clinical Virology, UPMC Presbyterian, Pittsburgh, PA 15213, USA.
} 


\section{Introduction}

The lungs are a large mucosal interface between the host and the environment, which in the adult human is estimated to be $75 \mathrm{~m}^{2}$ [1]. AIDS-defining illnesses that develop during the course of HIV-1 infection frequently involve the lungs. In retrospective analyses of pathologic specimens from HIV1-infected individuals at autopsy, 75-85\% of cases demonstrate pathologic involvement in the lung [2]. Among the most common pulmonary pathologies are those that involve infection by opportunistic pathogens including Pneumocystis carinii, Mycobacterium tuberculosis, Mycobacterium avium complex (MAC), and cytomegalovirus [3,4].

Infection of rhesus macaques with pathogenic strains of simian immunodeficiency virus (SIV) serves as an excellent model system for HIV-1 replication and disease induction, including increased susceptibility to pulmonary infections and pathology $[2,5]$. The mechanisms leading to increased pulmonary complications, though, are incompletely understood. The extent to which local SIV replication contributes to changes in immune function in the lungs of SIV-infected rhesus macaques is not clear, although viral replication in lung tissues is not extensive during the acute or chronic stage of infection [5-7]. In contrast, SIV productively infected cells can be abundant in lung tissues during AIDS, and increased levels of viral replication in the lungs have been shown to emerge in some cohorts of macaques during the transition from clinical latency to AIDS [5,6,8]. Similar to HIV-1 infection of humans, SIV infection of rhesus macaques frequently leads to pulmonary diseases, such as P. carinii pneumonia $[9,10]$. Although the mechanisms by which HIV-1 and SIV infections reduce the ability of infected hosts to resist pulmonary infections and pathology have not been fully elucidated, it is likely that HIV-1 and SIV induce changes, directly and indirectly, to the pulmonary immune environment.

To identify changes occurring in lung tissues during SIV infection, and thereby gain insight into mechanisms leading to pathologic outcomes, we have used three different cDNA microarrays, as well as in situ hybridization and real-time RT-PCR, to measure changes in gene expression. One of the cDNA arrays was a novel macaque cDNA microarray, which we generated to contain $>150$ immunologically relevant rhesus macaque cDNAs. Using these approaches, multiple IFN-inducible genes were identified as differentially expressed, including the IFN- $\gamma$-inducible chemokines, CXCL9/Mig and CXCL10/IP-10, which were among the most highly upregulated genes during AIDS. These findings indicate that both type I and type II IFNs are components of the host response to infection and its consequences, and contribute to restructuring of the pulmonary immune environment during pathogenic SIV infection.

\section{Materials and methods}

\subsection{Animals and tissue processing}

All animal studies were performed under the approval and guidance of the University of Pittsburgh Institutional Animal Care and Use Committee. The 12 adult rhesus macaques
(Macaca mulatta) of Indian origin used in this study, and their clinicovirologic states, have been previously described [7,11]. Paraformaldehyde-fixed and snap-frozen tissues were available from these animals. Total RNA was extracted from homogenized frozen tissues as described [11].

\subsection{Human cDNA filter array}

cDNA labeling, DNA array hybridizations and washes, and data extraction and analysis were performed as described [11], using the human cytokine filter arrays and cDNA labeling and hybridization kit (R\&D Systems, Minneapolis, MN). Equivalent masses of total RNA were combined to generate pools of RNA from rhesus macaques that were uninfected (macaques M5600 and M6600), acutely SIV infected (M5499, M5699, M0999, M5899 and M5999), or SIV infected and developing AIDS (M5199 and M1799).

\subsection{Human V cDNA microarray}

Pooled total RNAs $(150 \mu \mathrm{g})$ from the uninfected macaques (M5600 and M6600) and from two macaques with AIDS (M1799 and M5199) were sent to Incyte Genomics (Palo Alto, CA) and analyzed using the Human V cDNA microarray. To assure that the data analysis was based only on the most reliable measurements, the data were subjected to stringent filtering. A microarray signal (GEMTools ${ }^{\mathrm{TM}} 2.5$ software, Incyte) was deemed reliable if the intensity was $\geq 250$, the signal-to-background ratio was $\geq 2.5$, and the signal from the spotted area was $\geq 40 \%$. To allow for comparative analysis, genes were selected only if all signals for different disease states passed the quality-control thresholds. A significant differential expression value was generally considered to be \pm 2 -fold. Out of 9100 cDNA probes on the microarray, 45 passed these stringent criteria and were identified as being differentially expressed.

\subsection{Rhesus macaque cDNA microarrays}

To generate a custom-fabricated, macaque cDNA microarray, cDNAs were cloned from rhesus macaque tissues, DNA sequenced, PCR amplified, and spotted in sextuplicate onto Corning UltraGAPS slides (Corning Inc., Corning, NY), using the Affymetrix 417 Arrayer (Affymetrix, Santa Clara, CA). Each rhesus macaque cDNA was PCR amplified with a vector-specific forward primer and a gene-specific reverse primer. Spotted arrays were baked for $3 \mathrm{~h}$ at $80{ }^{\circ} \mathrm{C}$ and stored at room temperature. Prior to hybridization, arrays were hydrated over boiling water for $3 \mathrm{~s}$, UV-crosslinked (1200 mJ), incubated in 2-propanol for $15 \mathrm{~min}$ at room temperature, submersed in boiling deionized water for $10 \mathrm{~min}$, air dried, and equilibrated to $50{ }^{\circ} \mathrm{C}$.

Labeling of total RNA $(2 \mu \mathrm{g})$ was performed using the 3DNA Array 350 Expression Array Detection Kit (Genisphere Inc., Hatfield, PA) according to the manufacturer's recommendations. With this two-step system, RNAs were reverse transcribed using Array 350RP RT primers, ligated to dendrimer-specific capture oligonucleotides, and after array hybridization and washing were labeled by subsequent 
hybridization with Cy3-3DNA or Cy5-3DNA detection reagents. Labeled cDNAs in $25 \mu$ of hybridization buffer (Genisphere) were incubated at $75-80{ }^{\circ} \mathrm{C}$ for $10 \mathrm{~min}$, followed by incubation at $50{ }^{\circ} \mathrm{C}$ for $20 \mathrm{~min}$ before being applied to the pretreated slide. Slides were hybridized in a hybridization cassette at $50{ }^{\circ} \mathrm{C}$ overnight in a water bath and then washed $12 \mathrm{~min}$ sequentially in $2 \times \mathrm{SSC} / 0.2 \%$ SDS buffer $\left(60^{\circ} \mathrm{C}\right), 2 \times \mathrm{SSC}$ buffer $\left(25{ }^{\circ} \mathrm{C}\right), 0.2 \times \mathrm{SSC}$ buffer $\left(25{ }^{\circ} \mathrm{C}\right)$, followed by 2 min in $95 \%$ ethanol $\left(25^{\circ} \mathrm{C}\right)$. Slides were dried by centrifugation at $1000 \mathrm{rpm}$ for $2 \mathrm{~min}$ in a $50 \mathrm{ml}$ conical tube and re-equilibrated to $60{ }^{\circ} \mathrm{C}$. 3DNA capture reagents were then hybridized to the cDNA/dendrimer complexes hybridized to the probe cDNAs on the array, for $3 \mathrm{~h}$ at $50{ }^{\circ} \mathrm{C}$. Slides were then washed following the same protocol used after the cDNA hybridization. Hybridized and washed arrays were scanned with the Affymetrix 418 scanner (Affymetrix, Santa Clara, CA). Scanned TIFF images of $\mathrm{Cy} 3$ and $\mathrm{Cy} 5$ signals were analyzed using Imagene 5.5 software package (Biodiscovery Inc., Marina del Rey, CA). For these studies, we used the augmented reference design [12], in which each sample was hybridized against the same reference, which was pooled total RNA from two uninfected macaques. Signal intensities for individual lung RNA samples (Cy5) were normalized to the mean signal intensities for housekeeping genes expressed above background (mean of negative control spots plus two standard deviations), followed by normalization to the data acquired for the reference RNA sample (Cy3) hybridized and detected on the same slide. Student's $t$-tests and Mann-Whitney nonparametric tests were performed to identify mRNAs that were differentially expressed $(P<0.05)$ between disease states.

\subsection{Real-time RT-PCR}

Total RNAs obtained from homogenized, snap-frozen tissue specimens were examined using real-time RT-PCR as described [13]. The endogenous control used in these studies to normalize for input RNA was $\beta 2$-microglobulin ( $\beta 2 \mathrm{~m})$. PCR reactions were cycled at $95{ }^{\circ} \mathrm{C}$ for $12 \mathrm{~min}$, followed by 40 cycles of $95{ }^{\circ} \mathrm{C}$ for $15 \mathrm{~s}$ and $60{ }^{\circ} \mathrm{C}$ for $1 \mathrm{~min}$ on an ABI Prism 7000 Sequence Detection System (PE Applied Biosystems). Primers were designed using the Primer Express software package (PE Applied Biosystems) and consisted of the following sequences: SSRhMigF2 (5'-CAGATTCAGCAGATGTGAAGGAA-3'), SSRhMigR2 (5' ACGTTGAGATTTTCTAACTTTCAGAACTT- ${ }^{\prime}$ ), SSRhIP10 F4 (5'-TTGCTGCCTTGTCTTTCTGACTCTAA-3'), and SSRh IP10R4 (5'-AATTCTTGATGGCCTTCGATT-3'). The primer sequences for $\beta 2 \mathrm{~m}$ consisted of the following sequences: SSB2 MF4 (5'-ATGAGTATGCCTGCCGTGT-3') and SSB2MR4 $\left(5^{\prime}\right.$-ATGCTGCTTACATGTCTCGATC- $\left.3^{\prime}\right)$. The relative expression levels of CXCL9/Mig and CXCL10/IP-10 mRNA were calculated using the comparative $C_{\mathrm{T}}$ method [14] using macaque M5600 as the calibrator.

\subsection{P. carinii mitochondrial rRNA subcloning and sequencing}

The large subunit of the mitochondrial ribosomal RNA was amplified from an existing cDNA clone (kindly provided by
Dr. K. Norris, University of Pittsburgh), using previously described primers [15]. The amplified product (364 bp) was subcloned into the pGEMT vector and DNA sequenced.

\subsection{In situ hybridization and immunohistochemistry}

In situ hybridizations (ISHs) and simultaneous ISH and immunohistochemistry (IHC) were performed as described [11] using macaque-specific sequences for detection of cytokine mRNAs (plasmids kindly provided by Dr. F. Villinger, Emory University) or for detection of chemokine mRNAs, as described [11].

\subsection{Statistical analyses}

Student's $t$-tests, Mann-Whitney nonparametric tests, and Pearson's correlation analyses were performed using the Minitab software package.

\section{Results}

\subsection{Microarray identification of IFN-inducible genes as upregulated in rhesus macaque lung tissue during SIV infection}

To better understand changes that occur in pulmonary tissues during pathogenic SIV infection, we sought to identify genes that were differentially expressed in the lungs of SIV/DeltaB670-infected rhesus macaques during the course of infection. The animals from which tissues were obtained for these studies (Table 1) have been previously described [7,11]. Lung tissue RNAs from uninfected macaques and SIV-infected macaques developing AIDS were pooled by disease state and analyzed using a high-density cDNA microarray. Two rhesus macaques with AIDS and two uninfected controls [11] were included in this initial analysis.

Of the 9100 cDNA targets analyzed, $95.5 \%$ were less than 2-fold different in relative expression level between tissues from uninfected macaques and macaques with SIV-associated AIDS. Twenty-four genes were upregulated 2-fold or more during AIDS (Table 2). Of these, 10 were inducible by type I or type II interferons (IFNs) and four were chemokines. Interestingly, three of the upregulated genes encoded genetically and functionally related chemokines (CXCL9, CXCL10, and CXCL11), which are all IFN- $\gamma$-inducible and signal through chemokine receptor CXCR3 [16,17]. Notably, these included the most upregulated mRNA observed (CXCL10, 5.7-fold). The other upregulated mRNAs can be induced by IFN- $\alpha / \beta$ and other type I interferons and encoded myxovirus resistance $\mathrm{A}$ and $\mathrm{B}, \mathrm{IFI}-56 \mathrm{~K}$, guanylate-binding protein 1 , and $2^{\prime}-5^{\prime}$ oligoadenylate synthetase gene products. In addition, 21 genes were downregulated 2-fold or greater during AIDS (Table 2). Of these genes, the six most downregulated genes encoded acute phase, inflammatory response proteins, including albumin, fibrinogen $\alpha$ and $\beta$ polypeptides, serum amyloid A2, hemopexin, and haptoglobin.

We also used an immunologically focused human cDNA filter array to measure changes in gene expression in macaque 
Table 1

Animals, infection status, and SIV viral loads

\begin{tabular}{lllrl}
\hline Animal $^{\mathrm{a}}$ & $\begin{array}{l}\text { Duration } \\
\text { of infection } \\
\text { (weeks) }\end{array}$ & $\begin{array}{l}\text { Stage of } \\
\text { infection }\end{array}$ & $\begin{array}{l}\text { Plasma } \\
\text { viral load } \\
(\text { copies/ml })\end{array}$ & $\begin{array}{l}\text { Lung tissue } \\
\text { viral load }^{\mathrm{c}} \\
(\text { copies SIV/copies } \\
\beta 2 \mathrm{~m} \times 100)\end{array}$ \\
\hline M5600 & N/A & Uninfected & \multicolumn{1}{l}{ ND } & $<0.1$ \\
M6600 & N/A & Uninfected & ND & $<0.1$ \\
M5299 & 2 & Acute & $10,000,000$ & 9.9 \\
M5499 & 2 & Acute & $6,500,000$ & ND \\
M5599 & 2 & Acute & 54,000 & $<0.1$ \\
M5699 & 2 & Acute & $63,000,000$ & 31.6 \\
M0999 & 2 & Acute & $29,000,000$ & 6.9 \\
M5899 & 2 & Acute & $14,000,000$ & 4.8 \\
M5999 & 2 & Acute & $7,000,000$ & ND \\
M6299 & 2 & Acute & $34,000,000$ & 2.5 \\
M1799 & 21 & AIDS & 780,000 & 1.8 \\
M5199 & 24 & AIDS & 540,000 & 0.8 \\
M6199 & 32 & AIDS & 940,000 & 114.8 \\
M5799 & 55 & AIDS & $28,000,000$ & 1.5 \\
\hline ND5 & & & & \\
\hline
\end{tabular}

ND, not determined.

a These animals have been described previously [11], including their plasma viral loads, and this information has been included here for comparative purposes.

b Real-time RT-PCR was used to determine plasma viral loads.

c Real-time RT-PCR was used to determine tissue-associated viral loads, with normalization to the copy numbers of $\beta 2 \mathrm{~m}$ mRNA and multiplication $\times 100$.

lung tissues using the same total RNAs, as well as a pool of lung total RNAs obtained from five rhesus macaques acutely infected with SIV/DeltaB670. Genes that were differentially expressed, as defined by a 2 -fold or greater increase or decrease in mRNA expression, are presented in Table 3. Twenty genes were upregulated during AIDS and an overlapping subset of 20 genes were upregulated during acute infection, whereas seven genes were downregulated during AIDS, five of which also completely comprised the set of genes downregulated during acute infection. The upregulated genes encoded proteins involved in chemotaxis (CXCL9, CXCL10, CCL2 and CCL19), TNF/R superfamily signaling (LIGHT and TNFR II), cell adhesion (integrin- $\beta 4$, EpCAM, and L-selectin), angiogenesis (ephrins A2 and A3) and cytokine signaling (IFN- $\gamma \quad \mathrm{R} 2, \mathrm{IFN}-\alpha / \beta \quad \mathrm{R} \alpha$ and GM-CSF). Interestingly, CXCL10/IP-10 and CXCL9/Mig were both among the 10 most upregulated genes during AIDS, concordant with the high-density microarray data (Table 2). Using this cDNA array approach, upregulation of chemokine mRNA expression was not observed in lung tissues of acutely infected macaques relative to uninfected controls.

\subsection{Confirmation of CXCR3 ligand upregulation in lung tissues during SIV infection via development of a rhesus macaque-specific cDNA microarray}

To allow analysis of individual lung RNA samples and to follow-up on mRNAs identified as differentially expressed using the human arrays, we fabricated a microarray using macaque cDNAs. This initial collection of cDNAs represented
Table 2

Differentially expressed mRNAs in macaque lung tissues during SIV infection: high-density human (Incyte) cDNA microarray

\begin{tabular}{|c|c|c|}
\hline Gene & $\begin{array}{l}\text { GenBank } \\
\text { accession } \\
\text { number }\end{array}$ & $\begin{array}{l}\text { AIDS: } \\
\text { uninfected }^{\mathrm{a}}\end{array}$ \\
\hline CXCL10/IP-10 & NM_001565 & 5.7 \\
\hline Myxovirus resistance $\mathrm{A}^{\mathrm{b}}$ & BF972585 & 4.1 \\
\hline CXCL9/MIG & NM_002416 & 3.9 \\
\hline Myxovirus resistance B & XM_012984 & 3.5 \\
\hline $\begin{array}{l}\text { Nuclear receptor subfamily } 1 \text {, } \\
\text { group } \mathrm{H}, \text { member } 2\end{array}$ & BE878950 & 3.4 \\
\hline EST & AI609624 & 3.3 \\
\hline $\begin{array}{l}\text { Interferon-induced protein with } \\
\text { tetratricopeptide repeats } 1^{\mathrm{b}}\end{array}$ & NM_001548 & 3.2 \\
\hline IFI- $65 \mathrm{~K}^{\mathrm{b}}$ & NM_022872 & 2.9 \\
\hline $\begin{array}{l}\text { Interferon-induced, hepatitis } \\
\text { C-associated microtubular } \\
\text { aggregate protein }^{\mathrm{b}}\end{array}$ & XM_001628 & 2.5 \\
\hline EST & AI034385 & 2.3 \\
\hline $\begin{array}{l}\text { Guanylate binding protein } 1 \text {, } \\
\text { interferon-inducible, } 67 \mathrm{kD}^{\mathrm{b}}\end{array}$ & BF913224 & 2.2 \\
\hline Ets variant gene 2 & AF000671 & 2.2 \\
\hline Carboxypeptidase A3 (mast cell) & NM_001870 & 2.2 \\
\hline Selenophosphate synthetase 2 & AW9̄57160 & 2.2 \\
\hline Ring finger protein 3 & BF979824 & 2.2 \\
\hline Neuropeptide Y & K01911 & 2.2 \\
\hline CCL8/MCP-2 & AV734258 & 2.2 \\
\hline $\begin{array}{l}\text { Complement component } 1 \text {, } \\
\text { q subcomponent, beta polypeptide }\end{array}$ & AI879461 & 2.1 \\
\hline KIAA0756 protein & AB018299 & 2.1 \\
\hline Pleiomorphic adenoma gene-like 2 & XM_009541 & 2.0 \\
\hline CXCL11/I-TAC $^{\mathrm{b}}$ & $\mathrm{BC} 005292$ & 2.0 \\
\hline $\begin{array}{l}\text { Eukaryotic translation initiation } \\
\text { factor } 4 \mathrm{E}-\text {-like } 3\end{array}$ & BE960808 & 2.0 \\
\hline $2^{\prime}-5^{\prime}$ oligoadenylate synthetase $2^{\mathrm{b}}$ & XM_007001 & 2.0 \\
\hline $\begin{array}{l}\text { S100 calcium-binding protein A9 } \\
\text { (calgranulin B) }\end{array}$ & BG331778 & 2.0 \\
\hline Albumin & AL558086 & -10.2 \\
\hline Fibrinogen, A alpha polypeptide & AL564557 & -6.3 \\
\hline Serum amyloid A1 & AA829286 & -4.0 \\
\hline Hemopexin & AI133162 & -3.5 \\
\hline Haptoglobin & AL564563 & -3.3 \\
\hline Fibrinogen, B beta polypeptide & AI969333 & -2.6 \\
\hline Endothelial PAS domain protein 1 & AW377189 & -2.4 \\
\hline SPARC-like 1 (mast9, hevin) & NM_004684 & -2.3 \\
\hline Progastricsin (pepsinogen C) & NM_002630 & -2.3 \\
\hline Leptin receptor & NM_002303 & -2.3 \\
\hline $\begin{array}{l}\text { AHNAK nucleoprotein } \\
\text { (desmoyokin) }\end{array}$ & BG473688 & -2.2 \\
\hline Plasminogen & K02922 & -2.2 \\
\hline $\begin{array}{l}\text { Upregulated by } \\
\text { 1,25-dihydroxyvitamin D-3 }\end{array}$ & AU139227 & -2.2 \\
\hline Haptoglobin-related protein & BG545187 & -2.1 \\
\hline CDC-like kinase 1 & AK025306 & -2.1 \\
\hline $\begin{array}{l}\text { Delta sleep inducing peptide, } \\
\text { immunoreactor }\end{array}$ & AL561046 & -2.1 \\
\hline $\begin{array}{l}\text { Cytochrome P450, subfamily IVB, } \\
\text { polypeptide } 1\end{array}$ & NM_000779 & -2.1 \\
\hline Hypothetical protein FLJ20366 & XM_005157 & -2.0 \\
\hline Microfibrillar-associated protein 4 & AL569291 & -2.0 \\
\hline Thrombomodulin & AL049651 & -2.0 \\
\hline$\beta I$ spectrin & NM_003128 & -2.0 \\
\hline
\end{tabular}

${ }^{a}$ Ratio of normalized signal intensities for AIDS (M1799 and M5199) vs. uninfected (M5600 and M6600) macaque lung tissue RNAs.

${ }^{\mathrm{b}}$ Interferon (IFN)-inducible mRNAs. 
Table 3

Differentially expressed mRNAs in macaque lung tissues during SIV infections: human cytokine filter array

\begin{tabular}{|c|c|c|c|c|c|}
\hline Gene & $\begin{array}{l}\text { GenBank } \\
\text { accession } \\
\text { number }\end{array}$ & $\begin{array}{l}\text { AIDS: } \\
\text { UI }^{\mathrm{a}}\end{array}$ & Gene & $\begin{array}{l}\text { GenBank } \\
\text { accession } \\
\text { number }\end{array}$ & $\begin{array}{l}\text { Acute: } \\
\mathrm{UI}^{\mathrm{b}}\end{array}$ \\
\hline LIGHT & AF036581 & 5.8 & LIGHT & AF036581 & 5.9 \\
\hline Integrin- $\beta 4$ & X51841 & 4.4 & Integrin- $\beta 4$ & X51841 & 4.8 \\
\hline CXCL10/IP-10 & X02530 & 4.1 & Ephrin-A2 & AJ007292 & 3.3 \\
\hline Ephrin-A3 & U14187 & 4.0 & Ephrin-A3 & U14187 & 3.1 \\
\hline Ephrin-A2 & AJ007292 & 3.5 & CD6 & U34625 & 2.7 \\
\hline CD6 & U34625 & 3.0 & IL-1 R1 & X16896 & 2.6 \\
\hline CXCL9/MIG ${ }^{\mathrm{c}}$ & X72755 & 2.7 & TGF $\beta$ RI & M38449 & 2.5 \\
\hline EpCAM & $\mathrm{X} 13425$ & 2.6 & GPR-31 & U65402 & 2.5 \\
\hline CCL19/MIP-3 $\beta$ & AB000887 & 2.5 & FGF R3 & M58051 & 2.4 \\
\hline IFN- $\gamma$ R2 & U05875 & 2.4 & ММР-14 & D26512 & 2.4 \\
\hline TNF RII & M85079 & 2.2 & IL-15 $\mathrm{R} \alpha$ & U31628 & 2.4 \\
\hline CCL2/MCP-1 & S69738 & 2.3 & MMP-15 & D86331 & 2.3 \\
\hline MMP-14 & D26512 & 2.3 & RANK & AF018253 & 2.3 \\
\hline L-Selectin & M25280 & 2.2 & MIC-1 & AF019770 & 2.3 \\
\hline IFN- $\alpha / \beta \mathrm{R} \alpha$ & J03171 & 2.2 & IFN- $\gamma$ R2 & U05875 & 2.2 \\
\hline GM-CSF & M10663 & 2.2 & Integrin- $\alpha \mathrm{E}$ & L25851 & 2.2 \\
\hline BMP-8 & M97016 & 2.1 & BMP-8 & M97016 & 2.2 \\
\hline FGF R3 & M58051 & 2.1 & Inhibin A & M13918 & 2.1 \\
\hline Activin RIB & NM_004302 & 2.1 & CD27L & L08096 & 2.1 \\
\hline Urokinase R & Z46797 & 2.0 & Endothelin-2 & J05081 & 2.1 \\
\hline iNOS & L09210 & -6.0 & iNOS & L09210 & -5.8 \\
\hline Pleiotrophin & X52946 & -3.5 & CXCR5 & X68149 & -2.4 \\
\hline CNTF R $\alpha$ & M73238 & -3.0 & FGF R1 & M60485 & -2.1 \\
\hline CXCR5 & X68149 & -2.7 & ICAM-3 & S50015 & -2.0 \\
\hline FGF R1 & M60485 & -2.4 & Pleiotrophin & X52946 & -2.0 \\
\hline HB-EGF & M60278 & -2.2 & & & \\
\hline ICAM-3 & S50015 & -2.1 & & & \\
\hline
\end{tabular}

${ }^{\text {a }}$ Ratio of normalized signal intensities for AIDS vs. uninfected macaque lung tissue RNAs. The lung tissues examined were from the same animals as in Table 2. The gene products noted in bold were found to be differentially expressed during both acute infection and AIDS.

${ }^{\mathrm{b}}$ Ratio of normalized signal intensities acute vs. uninfected macaque lung tissue RNAs. The specific animals are noted in Section 2.

c Interferon (IFN)-inducible mRNAs.

151 rhesus macaque genes, including seven housekeeping genes, which were used for normalization. Of the 151 rhesus macaque cDNAs on the array, several major classes were represented, including chemokines and chemokine receptors, cytokines, dendritic cell (DC) and natural killer cell (NK)associated genes, and lymphocyte-associated genes. Each of the individual cDNA samples generated from macaque lung tissue RNAs was labeled with Cy5 and simultaneously hybridized with a common reference cDNA labeled with $\mathrm{Cy} 3$ and comprised of a pool of total RNAs from uninfected macaque lung tissues.

Table 4 shows the changes in lung mRNA expression for all genes determined to be differentially expressed. Genes were included in Table 4 if the ratios of the group (disease state) mean expression levels were $\geq 1.5$ or if statistical comparisons between disease states yielded a $P$-value $<0.05$ for at least one of the disease state comparisons. The data for a subset of these genes have been shown for individual macaque lung RNA preparations in Fig. 1. Use of this macaque cDNA microarray confirmed that mRNAs encoding all three CXCR3 ligands were upregulated in lung tissues of macaques that progressed to AIDS, relative to uninfected controls (Fig. 1). To compare these data to the data obtained using the two human cDNA arrays, we determined the mean fold-increases in mRNA expression by disease state including only the same animals used for the human cDNA array studies. The ratios below each gene product designation in Fig. 1 were calculated using the mean values of all macaques within each disease group, or using the mean values of the subset of macaques (two uninfected and two AIDS) from which the data in Tables 2 and 3 were generated.

During AIDS, six mRNAs were upregulated by 2 -fold or greater, although due to animal-to-animal variability these differences were not statistically significantly different. During acute infection no mRNAs were upregulated to this extent, yet four mRNAs were nevertheless upregulated based on statistical comparisons (Table 4). Interestingly, four of the six most upregulated genes were chemokines (Table 4). By all three array approaches, mRNAs encoding CXCL9/Mig and CXCL10/IP-10 were consistently among the most differentially expressed mRNAs. The data for mRNAs encoding CCL18/PARC and CD20 were included in Fig. 1 for comparative purposes. Comparing group means revealed a 3.17-fold increase in mRNA encoding CD20, although this was clearly contributed by one animal (M5799) that was determined to have a disseminated B-lymphocytic lymphoma. There were no genes differentially expressed when comparing lung samples from acutely SIV-infected macaques to those of uninfected controls. These data are concordant with the previous array data revealing the potent upregulation of mRNAs encoding CXCR3 ligands during AIDS.

\subsection{Quantitation of IFN-inducible mRNA levels using real-time RT-PCR analysis of lung tissues}

To further measure the extent of differential expression of genes identified by the three cDNA array analyses, we developed real-time RT-PCR assays specific for a subset of these genes. In the group of acutely infected macaques, the CXCL9/Mig mRNA expression levels in lung tissues were not different from those in the pair of uninfected controls (Fig. 2). However, in macaques that developed AIDS, CXCL9/Mig mRNA was expressed from 1.7- to 59.4-fold higher than the uninfected calibrator, with a mean of 22.5fold (Fig. 2). Macaques M1799 and M5199, RNAs from which had been pooled for analysis using the two commercially available arrays, displayed high CXCL9/Mig expression levels, which were 10.9- and 59.4-fold higher than the uninfected calibrator (Fig. 2), respectively. In acutely infected macaques, the CXCL10/IP-10 mRNA expression levels were from 1.7- to 5.8-fold higher (mean of 3.4-fold) than the uninfected calibrator, whereas in macaques that developed AIDS the increases were from 2.0- to 15.3-fold (mean of 8.4-fold; Fig. 2). As with CXCL9/Mig, macaques M1799 and M5199 displayed high CXCL10/IP-10 mRNA expression levels with an upregulation of 10.7- and 15.3-fold compared to uninfected macaques (Fig. 2), respectively. Finally, concordant with the CXCL9/Mig and CXCL10/IP-10 expression levels, IFN- $\gamma$ 
Table 4

Differentially expressed mRNAs in macaque lung tissues: custom-fabricated, macaque cDNA array

\begin{tabular}{|c|c|c|c|c|c|c|c|c|c|}
\hline \multirow[t]{2}{*}{ Gene } & \multicolumn{3}{|l|}{ Ac:UI } & \multicolumn{3}{|c|}{ AIDS:UI } & \multicolumn{3}{|c|}{ AIDS:Ac } \\
\hline & $\begin{array}{l}\text { Fold- } \\
\text { change }\end{array}$ & $\begin{array}{l}t \text {-test }{ }^{\mathrm{a}} \\
P \text {-value }\end{array}$ & $\begin{array}{l}\text { MW } \\
\text { test }^{\mathrm{a}} \text {, } \\
P \text {-value }\end{array}$ & $\begin{array}{l}\text { Fold- } \\
\text { change }\end{array}$ & $\begin{array}{l}t \text {-test, } \\
P \text {-value }\end{array}$ & $\begin{array}{l}\text { MW } \\
\text { test, } \\
P \text {-value }\end{array}$ & $\begin{array}{l}\text { Fold- } \\
\text { change }\end{array}$ & $\begin{array}{l}t \text {-test, } \\
P \text {-value }\end{array}$ & $\begin{array}{l}\text { MW } \\
\text { test, } \\
P \text {-value }\end{array}$ \\
\hline \multicolumn{10}{|l|}{ Upregulated } \\
\hline P. carinii $16 \mathrm{~S}$ rRNA & $0.94^{\mathrm{b}}$ & - & - & $8.65^{\mathrm{b}}$ & - & - & 9.22 & 0.047 & - \\
\hline CXCL9/Mig & 1.29 & - & - & 6.74 & - & - & 5.20 & - & - \\
\hline CD20 & 1.28 & - & - & 3.17 & - & - & 2.47 & - & - \\
\hline CXCL11/I-TAC & 1.58 & 0.038 & 0.050 & 3.14 & - & - & 1.99 & - & - \\
\hline CXCL10/IP-10 & 1.70 & 0.011 & 0.050 & 2.62 & - & - & 1.54 & - & - \\
\hline $\mathrm{CXCL} 1 / \mathrm{GRO} \alpha$ & 1.11 & - & - & 2.11 & - & - & 1.91 & - & - \\
\hline CXCL13/BCA-1 & 1.14 & - & - & 1.97 & - & - & 1.72 & - & - \\
\hline CD83 & 1.03 & - & - & 1.89 & - & - & 1.84 & - & - \\
\hline SIV LTR & 1.48 & - & - & 1.87 & - & - & 1.26 & - & - \\
\hline CD68 & 1.19 & - & - & 1.86 & - & - & 1.56 & - & - \\
\hline CD86 & 1.28 & - & - & 1.85 & - & - & 1.44 & - & - \\
\hline CCL19/MIP-3 $\beta$ & 1.28 & - & - & 1.77 & - & - & 1.38 & - & - \\
\hline Granzyme B & 1.93 & - & - & 1.70 & - & - & 0.88 & - & - \\
\hline TCR- $\beta$ & 1.29 & - & - & 1.68 & - & - & 1.30 & - & - \\
\hline $\mathrm{TNF} \alpha$ & 0.97 & - & - & 1.66 & - & - & 1.72 & - & - \\
\hline DEC-205 & 1.11 & - & - & 1.66 & - & - & 1.49 & - & - \\
\hline CXCL3/GRO- $\gamma$ & 1.16 & - & - & 1.64 & - & - & 1.42 & - & - \\
\hline CCL8/MCP-2 & 1.17 & - & - & 1.55 & - & - & 1.33 & - & - \\
\hline CD38 & 1.28 & - & - & 1.55 & - & - & 1.22 & - & - \\
\hline CCL3/MIP- $\alpha$ & 1.04 & - & - & 1.53 & - & - & 1.47 & - & - \\
\hline CCL29/MEC & 1.29 & - & - & 1.49 & - & - & 1.15 & - & - \\
\hline DAP10 & 1.09 & - & - & 1.48 & - & - & 1.36 & - & - \\
\hline CXCL8/IL-8 & 0.96 & - & - & 1.46 & - & - & 1.53 & - & - \\
\hline Dectin & 1.14 & - & - & 1.46 & - & - & 1.28 & - & - \\
\hline $\mathrm{IFN} \gamma$ & 1.18 & - & - & 1.45 & - & - & 1.23 & - & - \\
\hline$\beta$-2-Microglobulin & 1.62 & 0.036 & 0.050 & 1.40 & - & - & 0.86 & - & - \\
\hline $\mathrm{IFN} \gamma \mathrm{R} 1$ & 1.38 & 0.026 & - & 1.32 & - & - & 0.96 & - & - \\
\hline Calmodulin-2 & 0.99 & - & - & 0.94 & - & - & 0.95 & 0.049 & - \\
\hline \multicolumn{10}{|l|}{ Downregulated } \\
\hline PIN & 0.82 & - & - & 0.87 & 0.006 & - & 1.07 & - & - \\
\hline Decorin & 1.02 & - & - & 0.70 & - & - & 0.69 & 0.043 & 0.051 \\
\hline CD31 & 0.79 & - & - & 0.68 & - & - & 0.86 & - & - \\
\hline $\begin{array}{l}\text { Von Willebrand's } \\
\text { factor }\end{array}$ & 0.78 & - & - & 0.63 & - & - & 0.81 & - & - \\
\hline Pleiotrophin & 0.85 & - & - & 0.52 & - & - & 0.61 & - & - \\
\hline
\end{tabular}

a $P$-values $\leq 0.05$ shown are those derived from $t$-test and Mann-Whitney statistical analyses.

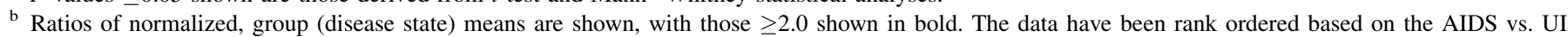
comparison.

mRNA levels were increased 2.6-fold during acute infection and 5.9-fold during AIDS (Fig. 2).

In addition to these highly upregulated, IFN- $\gamma$-inducible chemokines, we also examined the changes in expression of additional mRNAs which the cDNA arrays indicated either did not change or were up- or down-modulated during SIV infection. These analyses were of mRNAs encoding MxA, $\mathrm{CD} 27$, or albumin, and revealed that similar to our findings with the cDNA microarrays, mRNA for MxA was upregulated during AIDS and acute infection, and mRNA for CD27 was neither up- nor downregulated to an appreciable extent in macaque lung tissues (Fig. 2). Decreased expression of mRNA encoding albumin was observed, due to the effects of two animals during both acute infection and AIDS (Fig. 2), consistent with the downregulation indicated by the highdensity human cDNA array analyses (Table 2). In summary, real-time RT-PCR analyses were highly concordant with the cDNA microarray data for the subset of genes examined and further indicate that mRNAs encoding CXCR3 ligands are highly upregulated, particularly during AIDS.

\subsection{Macrophages are the predominant source of induced CXCR3 ligand production in lung tissues}

Given the consistent upregulation of a subset of chemokine mRNAs among the three cDNA array analyses, and their roles in inflammation, we focused next on their expression patterns within tissues by using in situ hybridization (ISH) with genespecific $\left[{ }^{35} \mathrm{~S}\right]$-labeled riboprobes. Expression of the three CXCR3 ligand mRNAs was minimal in lung tissues from uninfected and acutely infected macaques, but was upregulated in nearly all animals with AIDS (Table 5). In uninfected and 


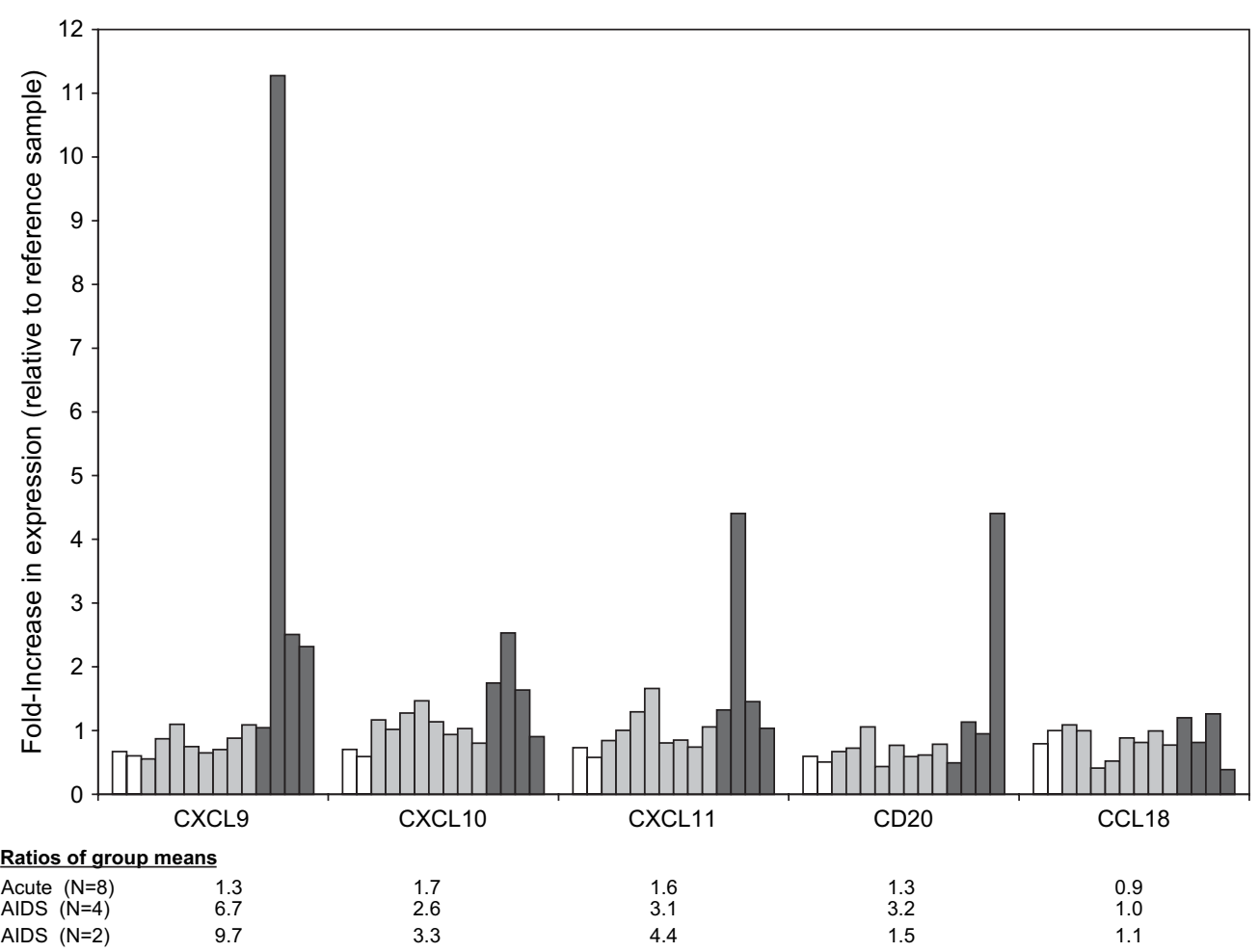

Fig. 1. Microarray analysis of differentially expressed mRNAs in macaque lung tissues during SIV infection. The relative mRNA expression levels of 151 immunologically relevant, macaque genes were measured using a custom-fabricated, high-density cDNA microarray. Expression levels for differentially expressed genes are shown as the fold-increase in mRNA expression, relative to a pooled uninfected reference RNA sample simultaneously hybridized on each microarray. Uninfected macaques are represented by the white bars, macaques with acute SIV infection are represented by the light gray bars, and animals with AIDS are represented by the dark gray bars. The order in which the animals have been presented is M5600, M6600, M5299, M5499, M5599, M5699, M5899, M5999, M6299, M0999, M1799, M5199, M6199 and M5799. The ratios of group means are all relative to the uninfected control group, with the top set of ratios (acute $N=8$ and AIDS $N=4$ ) inclusive of all animals and the lower set of ratios inclusive of only the two macaques with AIDS (M1799 and M5199) that were used for the human cDNA array studies in Tables 1 and 2.

acutely infected macaques, CXCR3 ligand $\mathrm{mRNA}^{+}$cells were rare and generally scattered throughout the interstitium, and to a lesser extent in alveolar spaces. In animals with AIDS, cells expressing these chemokine mRNAs were not only similarly scattered throughout the tissue, but also localized to larger focal collections (Fig. 3A). The ISH signal intensity of CXCL 11/I-TAC mRNA was lower relative to CXCL9/Mig and CXCL10/IP-10 (Table 4). In contrast, the patterns of expression of CCL18/PARC were generally high, regardless of disease state. Finally, simultaneous application of immunohistochemistry for CD68 and ISH for chemokine mRNA revealed that CXCL9/Mig mRNA ${ }^{+}$cells were predominantly CD68 ${ }^{+}$ monocytes/macrophages (Fig. 3D).

\subsection{CXCR3 ligand induction in macaque lung tissues is linked with local IFN- $\gamma$ and P. carinii levels}

To identify potential causes for the increased chemokine mRNA expression, we determined the patterns and levels of expression of cellular and pathogen RNAs within lung tissues. We first examined the distributions of cells expressing IFN- $\gamma$ mRNA, given that the CXCR3 ligands are inducible by this cytokine [17]. As measured by ISH and consistent with the real-time RT-PCR measurements (Fig. 2), IFN- $\gamma \mathrm{mRNA}^{+}$ cells were rare in all animals, although they were more abundant in lung tissues from animals with AIDS (Table 5), consistent with the increased levels of expression of CXCR3 ligand mRNAs observed by microarray and real-time RT-PCR.

The opportunistic infections that develop within the lungs during HIV-1 and SIV infections, as well as SIV per se, can potentially contribute to induction of chemokine expression through pattern recognition receptors of the innate immune system [18]. Therefore, we determined the levels and patterns of expression of SIV and $P$. carinii in the macaque lung tissues. Microarray and real-time RT-PCR measurements revealed that SIV RNA levels in lung tissues were present, but not abundant (Fig. 4A and Table 1). These findings were fully concordant with our previous ISH analyses [7] of lung tissues from these same macaques.

Among the macaques that developed AIDS, two macaques determined through the microarray analysis to have increased pulmonary expression of CXCL9/Mig and CXCL10/IP-10 (M5199 and M1799) were subsequently identified as having been spontaneously infected with $P$. carinii [10]. Our custom microarray also contained a probe for $P$. carinii rRNA, and analysis of the array data revealed that for macaques M1799 and M5199, the $P$. carinii rRNA array signal intensities were 19.3- and 4.6-fold higher, respectively, than the reference 


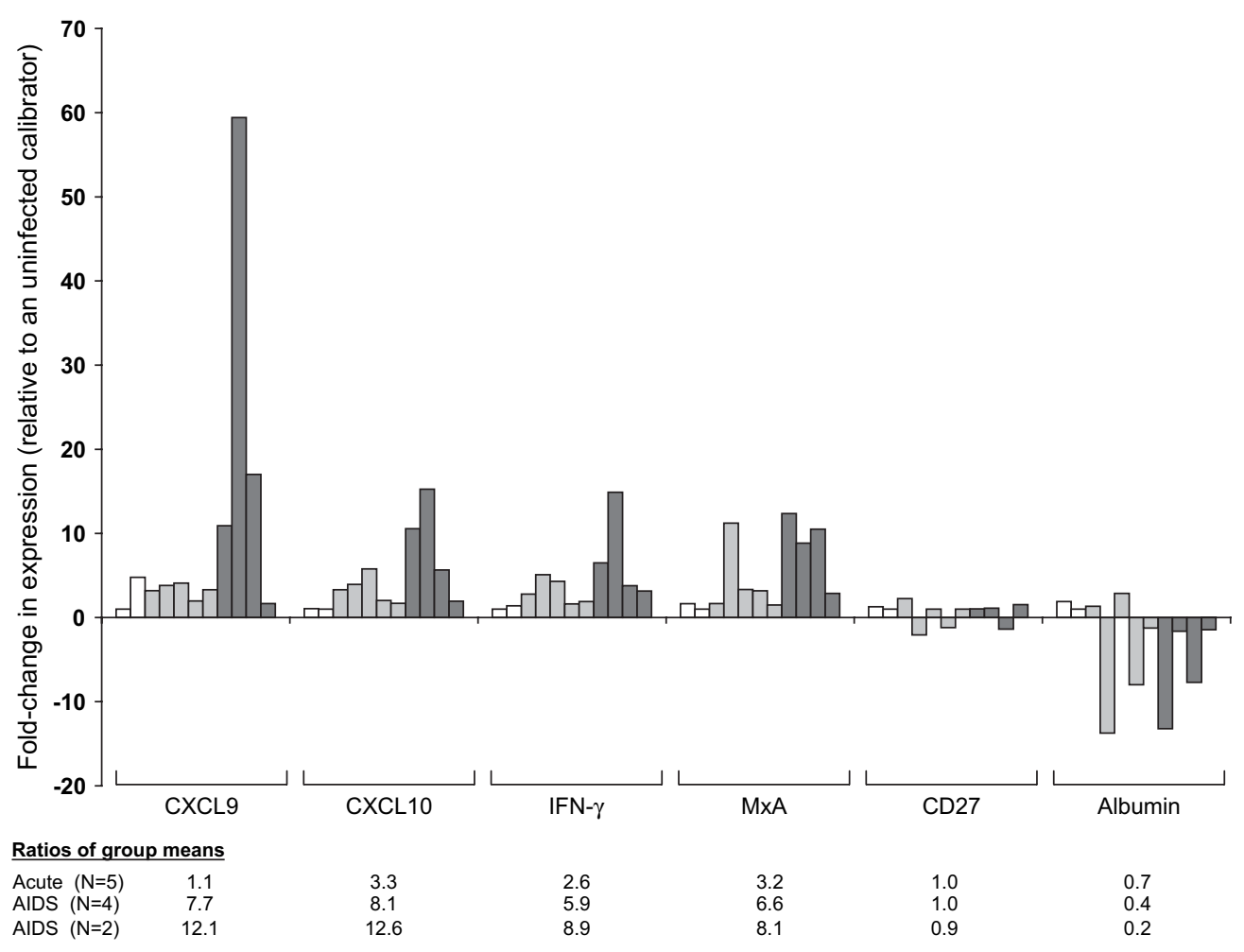

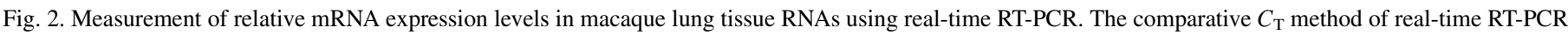

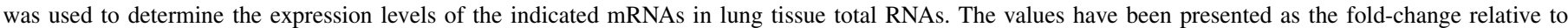

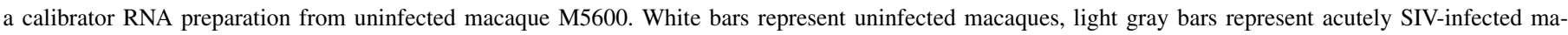

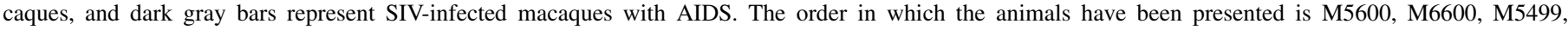
M5699, M5899, M5999, M0999, M1799, M5199, M6199, M5799.

(uninfected) lung sample (Fig. 4A). The $P$. carinii microarray signal intensities for all other macaques were all less than 2fold higher than the uninfected controls (Fig. 4A). To examine $P$. carinii expression directly in lung tissue sections, we developed an ISH assay for $P$. carinii mitochondrial rRNA. Consistent with the microarray data, ISH revealed that $P$. carinii rRNA was not present in uninfected or acutely infected animals, or in two of the macaques with AIDS (Fig. 4A, bottom). Among the two macaques with $P$. carinii ISH signal, M5199 had low levels of $P$. carinii rRNA expression in three out of five lobes of lung (Fig. 4C), whereas animal M1799 had abundant expression of $P$. carinii rRNA in all five lobes of lung examined (Fig. 4D).

To further understand the events leading to altered gene expression patterns in lung tissues during SIV infection of macaques, we performed correlation analyses among the levels of expression of the mRNAs we determined to be differentially expressed by microarray and real-time RT-PCR analyses, as well as SIV and $P$. carinii RNA levels. As shown in Table 6, IFN- $\gamma$, CXCL9/Mig, and CXCL10/IP-10 mRNA levels were all significantly positively correlated, suggesting that IFN- $\gamma$ played a major role in the induction of these chemokines. With respect to $P$. carinii rRNA microarray hybridization signals, only CXCL10/IP-10 mRNA levels measured by real-time RT-PCR were marginally significantly correlated. In addition, CXCL10/IP-10 and MxA mRNA levels were strongly positively correlated, suggesting that local or systemic IFN- $\alpha / \beta$ was also contributing to restructuring of the pulmonary immune environment. SIV RNA levels as measured by real-time RT-PCR were only correlated with SIV RNA levels determined by microarray hybridization. These analyses indicated that for these genes, microarray hybridization was reasonably quantitative and concordant with the more robust quantitative nature of real-time RT-PCR. These analyses also strongly suggest that the host immune response, in this case local IFN- $\gamma$ mRNA levels and local or systemic IFN- $\alpha / \beta$ levels, as opposed to local SIV replication per se, are driving local CXCR3 ligand expression patterns. In addition, local opportunistic pathogens, such a $P$. carinii, might also play a direct or indirect role in stimulating local chemokine production.

\section{Discussion}

Pulmonary complications and pathology are frequent outcomes of HIV-1 infection [2], and obtaining an increased understanding of the immunologic alterations that occur in the lungs during HIV-1 infection will be important for the rational development of additional strategies for the treatment of these complications. Using the SIV/macaque model of HIV-1 infection and disease, we sought here to identify genes differentially expressed in lung tissues during SIV infection and AIDS. Using cDNA microarray hybridization, we identified IFN-stimulated genes (ISGs) as the most prominent class of mRNAs that were upregulated in lung tissues during the early 

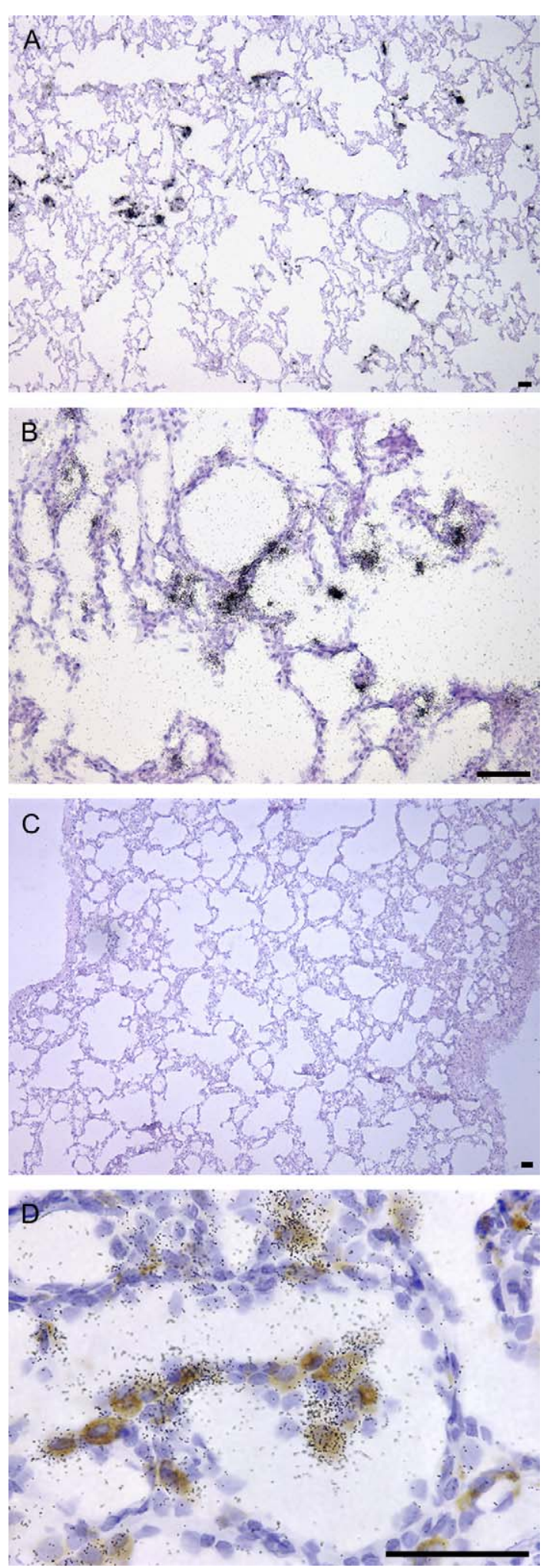

Fig. 3. In situ hybridization detection of CXCL9/Mig mRNA in macaque lung tissues. CXCL9/Mig mRNA was detected in lung tissue sections from an SIV-infected macaque that developed AIDS (M5199), using ISH with a radiolabeled antisense riboprobe (A,B). Hybridization with the control sense riboprobe revealed no specific ISH signal (C). In (D) ISH for CXCL9/Mig mRNA was performed simultaneously with IHC staining for the macrophage marker CD68. Black speckles represent the ISH autoradiographic signal, whereas brown staining represents IHC signal. Size bar, $50 \mu \mathrm{m}$.
Table 5

In situ hybridization signals for cellular mRNAs in rhesus macaque lung tissues during SIV infection

\begin{tabular}{lllllll}
\hline Disease state & Animal & IFN- $\gamma$ & CXCL9 & CXCL10 & CXCL11 & CCL18 \\
\hline Uninfected & M5600 & ${ }^{\mathrm{a}}$ & \pm & \pm & \pm & +++ \\
& M6600 & \pm & \pm & \pm & - & +++ \\
Acute & M5299 & - & + & + & + & +++ \\
& M5499 & - & \pm & + & + & +++ \\
& M5599 & - & \pm & \pm & + & \pm \\
& M5699 & - & \pm & + & + & ++ \\
& M5899 & - & + & + & + & +++ \\
& M5999 & - & + & + & \pm & +++ \\
AIDS & M6299 & \pm & $+{ }^{\mathrm{b}}$ & $+{ }^{\mathrm{b}}$ & $+{ }^{\mathrm{b}}$ & +++ \\
& M0999 & - & \pm & + & \pm & +++ \\
& M1799 & + & + & ++ & ++ & +++ \\
& M5199 & + & ++ & ++ & +++ & ++ \\
& M6199 & \pm & + & + & ++ & +++ \\
& M5799 & + & ++ & ++ & + & + \\
\hline
\end{tabular}

\pm , rare $\mathrm{mRNA}^{+}$cells in entire tissue section;,$+ 1-5 \mathrm{mRNA}^{+}$cells per $200 \times$ field;,$++ 6-10 \mathrm{mRNA}^{+}$cells per $200 \times$ field;,$+++>10 \mathrm{mRNA}^{+}$cells per $200 \times$ field.

a No signal detected.

b Cells expressing chemokine mRNAs were localized in discrete foci.

and late stages of infection. Among these ISGs, the IFN$\gamma$-inducible chemokines that signal through CXCR3 were consistently and strongly upregulated and we therefore closely examined the levels and patterns of expression of these inflammatory molecules.

To identify mRNAs differentially expressed in macaque lung tissues during the course of pathogenic SIV infection, we used three different microarrays. Using the human cDNA arrays we measured the relative mRNA expression levels between lung RNAs pooled by disease state, whereas with our custom-fabricated macaque array we measured the relative mRNA expression levels between individual macaques. Our results do not resolve the issue as to whether examination of pooled or individual RNA preparations is preferable, although they demonstrate that differences between pooled RNA preparations can result from extreme RNA expression levels in a subset of animals within groups.

All three of our microarray approaches revealed that the mRNAs encoding inflammatory chemokines CXCL9/Mig, CXCL10/IP-10, and CXCL11/I-TAC were consistently among the most highly upregulated genes in macaque lung tissues during SIV infection, out of the nearly 10,000 genes examined collectively. Increased CXCL10/IP-10 levels have been demonstrated during HIV/SIV infection in such compartments as plasma [19], PBMC [20], brain [21, 22] and lymph nodes $[13,23]$. Here we found that increased expression of CXCL9/ Mig occurred predominantly in $\mathrm{CD} 68^{+}$macrophages, concordant with the findings that CXCL10/IP-10 is upregulated in macrophages in lungs in the SHIV/macaque model [24]. The CXCL9-11 chemokines are ligands for CXCR3, which is expressed on activated T-lymphocytes, particularly those that are type-1 polarized [25], as well as a number of other cell types such as activated natural killer (NK) cells and plasmacytoid DC. Therefore, the inflammatory consequences of 
A

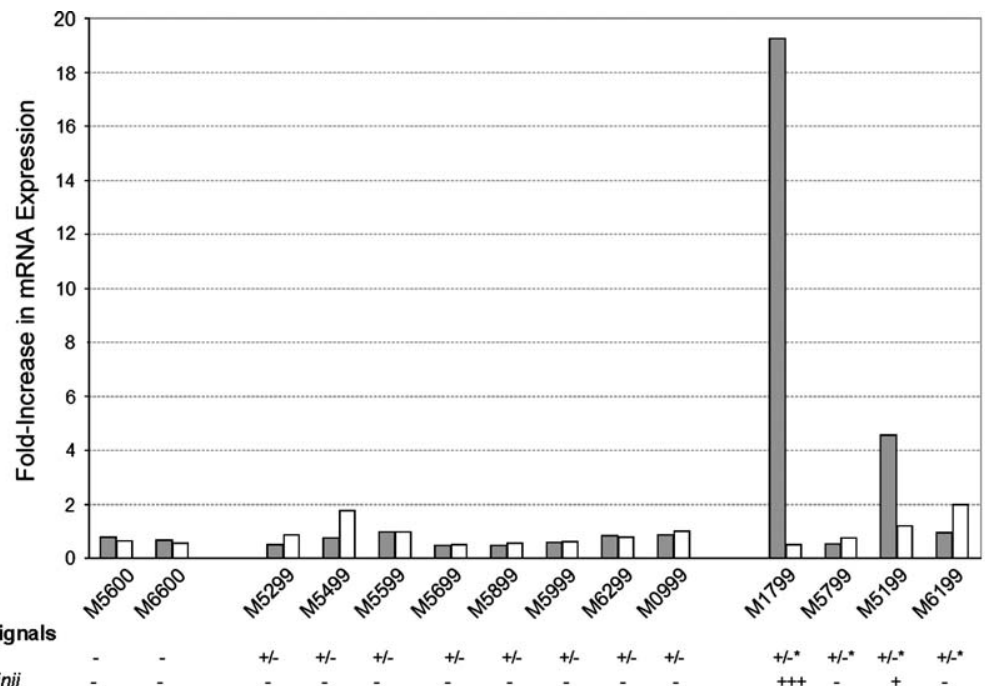

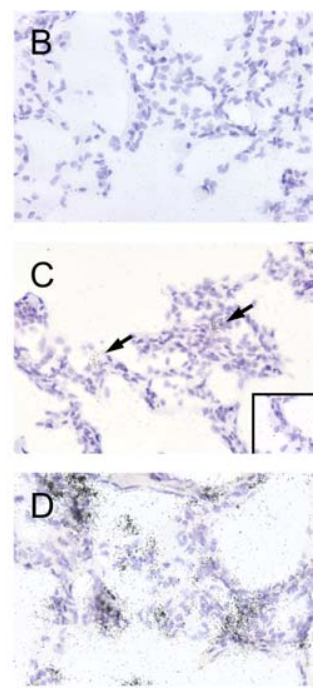

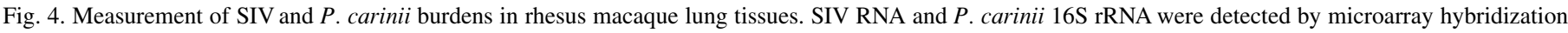

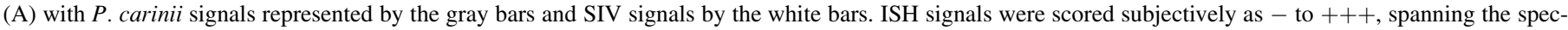

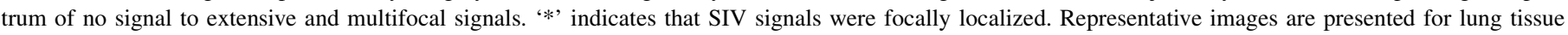

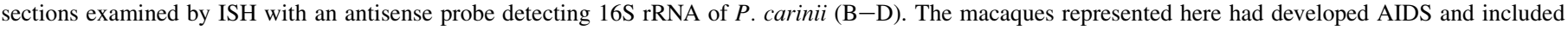

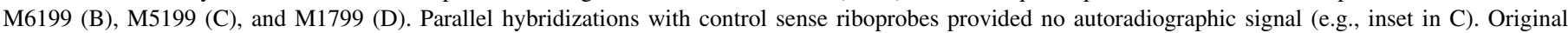
magnifications, $200 \times$.

increased CXCR3 ligand expression are likely to be complex and to affect both innate and adaptive immune responses within the lungs, which might allow opportunistic infections to gain a foothold in the lungs during development of immunodeficiency. Interestingly, the chemokine receptor, proliferation, and memory status of $\mathrm{T}$ cells trafficking to lung tissues differ among SIV-infected animals that progress to AIDS at normal as compared to rapid rates [26], which could be controlled in part by chemokine profiles.

The CXCR3 ligands we have found to be upregulated in the lung during AIDS are components of a positive amplification loop involving the recruitment of type 1 T-lymphocytes that produce IFN- $\gamma$, which then induces expression of CXCL9-11, which subsequently fuels an ongoing IFN- $\gamma$-driven feedback loop. We previously proposed that such a positivefeedback loop initiated by SIV-specific immune responses in lymphoid tissues of SIV-infected macaques contributes to the development of immunodeficiency [11]. Similar amplification loops might also be operating in pulmonary tissues. Key differences in these compartments, though, are the higher levels of viral replication in lymphoid tissues and the greater opportunity to encounter different opportunistic pathogens in lung tissues. One consequence of these inflammatory events will be to bring into local environments new cellular substrates for ongoing viral propagation. In addition, the constant ingress of cells that are producing matrix metalloproteinases to assist migration through tissues could lead to tissue damage and loss of barrier protection from infection. CXCR3 ligands are also antagonists for CCR3, which is expressed on type 2 T-lymphocytes and eosinophils [27], potentially further polarizing the net cytokine environment within the lungs and reducing recruitment of eosinophils and reducing the ability to combat pulmonary infections.
In parallel with the chemokines induced by IFN- $\gamma$, genes inducible by type I IFNs were also upregulated. Similar sets of genes have been shown to be upregulated in macaque brain tissues during SIV infection [28], suggesting that the signals for induction either occur simultaneously in multiple tissues or are systemically distributed through the bloodstream. We and others [20] have shown that IFN- $\gamma$ is expressed locally within the lungs during SIV infection, but preliminary analyses of IFN- $\alpha$ mRNA expression in lung tissues from the macaques studied here suggest that IFN- $\alpha$ is not made abundantly within the lungs (data not shown), although other locally produced IFNs could participate in shaping the local gene expression profile. The limited levels of SIV replication we have consistently observed in lung tissues of macaques (Fig. 4; [7]) suggest that the local response to IFN might contribute to the ability to hold local virus replication in check, as suggested by in vivo and in vitro studies [29].

The causes leading to the upregulation of these genes are not entirely clear, but are undoubtedly multifactorial. The nature of the innate and adaptive immune responses in the lung tissues of these animals must be a contributing factor to changes in the pulmonary gene expression profile. In support of this, we identified strong correlations between the levels of IFN- $\gamma$ and CXCR3 ligand mRNAs. Similarly, although we have not yet identified the source of type I IFNs, the induction of genes responsive to IFN- $\alpha / \beta$ indicates that these innate immune cytokines also play a role in shaping the differential gene expression profiles in lung tissues during SIV infection. One potential source of type I IFN is the abundant network of lymphoid tissues, which in these animals [13] and in others [30] have increased expression of IFN- $\alpha$ mRNA. In addition, upstream inducers of type I IFNs include pathogenassociated molecular patterns (PAMPs) that signal through 
Table 6

Correlations between relative mRNA expression levels in rhesus macaque lung tissues during SIV infection

\begin{tabular}{|c|c|c|}
\hline $\begin{array}{l}\text { Gene-specific } \\
\text { mRNA }\end{array}$ & $\begin{array}{l}\text { Comparison gene- } \\
\text { specific mRNA }\end{array}$ & $\begin{array}{l}\text { Pearson's correlation } \\
\text { coefficient ( } P \text {-value })\end{array}$ \\
\hline$\overline{C X C L 10 / I P-10^{a}}$ & $\begin{array}{l}\text { CXCL9/Mig } \\
\text { MxA } \\
\text { IFN- } \gamma \\
\text { P. carinii (microarray) } \\
\text { CXCL9/Mig (microarray) } \\
\text { CXCL10/IP-10 (microarray) }\end{array}$ & $\begin{array}{l}0.862(0.001)^{\mathrm{b}} \\
0.678(0.022) \\
0.945(<0.001) \\
0.591(0.055) \\
0.778(0.005) \\
0.949(<0.001)\end{array}$ \\
\hline CXCL9/Mig & $\begin{array}{l}\text { CXCL10/IP-10 } \\
\text { IFN- } \gamma \\
\text { CXCL9/Mig (microarray) } \\
\text { CXCL10/IP-10 (microarray) }\end{array}$ & $\begin{array}{l}0.862(0.001) \\
0.928(<0.001) \\
0.970(<0.001) \\
0.860(0.001)\end{array}$ \\
\hline MxA & $\begin{array}{l}\text { CXCL10/IP-10 } \\
\text { IFN- } \gamma \\
\text { CXCL10/IP-10 (microarray) } \\
\text { Albumin }\end{array}$ & $\begin{array}{r}0.678(0.022) \\
0.589(0.057) \\
0.801(0.003) \\
-0.811(0.002)\end{array}$ \\
\hline IFN- $\gamma$ & $\begin{array}{l}\text { CXCL9/Mig } \\
\text { CXCL10/IP-10 } \\
\text { MxA } \\
\text { CXCL9/Mig (microarray) } \\
\text { CXCL10/IP-10 (microarray) }\end{array}$ & $\begin{array}{l}0.928(<0.001) \\
0.945(<0.001) \\
0.589(0.057) \\
0.899(<0.001) \\
0.932(<0.001)\end{array}$ \\
\hline SIV & $\begin{array}{l}\text { SIV (microarray) } \\
\text { CD27 }\end{array}$ & $\begin{array}{r}0.800(0.010) \\
-0.744(0.021)\end{array}$ \\
\hline Albumin & $\begin{array}{l}\mathrm{CD} 27 \\
\mathrm{MxA}\end{array}$ & $\begin{array}{r}0.710(0.014) \\
-0.811(0.002)\end{array}$ \\
\hline $\mathrm{CD} 27$ & $\begin{array}{l}\text { SIV } \\
\text { Albumin }\end{array}$ & $\begin{array}{r}-0.744(0.021) \\
0.710(0.014)\end{array}$ \\
\hline $\begin{array}{r}\text { CXCL10/IP-10 } \\
\text { (microarray) }\end{array}$ & $\begin{array}{l}\text { CXCL9/Mig } \\
\text { CXCL10/IP-10 } \\
\text { IFN- } \gamma \\
\text { CXCL9/Mig (microarray) } \\
\text { MxA }\end{array}$ & $\begin{array}{l}0.860(<0.001) \\
0.949(<0.001) \\
0.932(<0.001) \\
0.784(0.004) \\
0.801(0.003)\end{array}$ \\
\hline $\begin{array}{l}\text { CXCL9/Mig } \\
\text { (microarray) }\end{array}$ & $\begin{array}{l}\text { CXCL9/Mig } \\
\text { CXCL10/IP-10 } \\
\text { IFN- } \gamma \\
\text { CXCL10/IP-10 (microarray) }\end{array}$ & $\begin{array}{l}0.970(0.001) \\
0.778(0.005) \\
0.899(<0.001) \\
0.784(0.004)\end{array}$ \\
\hline $\begin{array}{l}\text { P. carinii } \\
\text { (microarray) }\end{array}$ & CXCL10/IP-10 & $0.591(0.055)$ \\
\hline $\begin{array}{l}\text { SIV } \\
\text { (microarray) }\end{array}$ & SIV & $0.800(0.010)$ \\
\hline
\end{tabular}

\footnotetext{
a The measurements of mRNA expression that were compared were obtained by real-time RT-PCR, unless indicated in parentheses for those obtained by cDNA microarray hybridization.

${ }^{b}$ Shown here are those comparisons for which $P<0.05$ or for which the $P$-value was close to 0.05 .
}

germline-encoded Toll-like receptors [18], and therefore SIV, $P$. carinii and other microbes could contribute to the upregulation of the ISGs, particularly if overall immunodeficiency of the host allows pulmonary microbes to colonize and replicate in the lungs. Although we did not observe an absolute association between levels of $P$. carinii rRNA, the group of animals with AIDS as a whole had the highest levels of induction of IFN-stimulated genes and additionally contained the only two macaques with demonstrable $P$. carinii rRNA. In addition, the only host mRNA correlated with $P$. carinii rRNA levels was CXCL10/IP-10. Consistent with our findings, induction of CXCL10/IP-10 in macaques infected with SHIV is associated with the development of pneumonia [24]. Therefore, both the strength and nature of the host immune response and the constellation of microbes in the local environment likely create a set of signals that alter host gene expression profiles.

These findings have implications for the treatment and prevention of HIV-associated pulmonary complications. There is clearly a need to continue to chemotherapeutically target HIV1 and microbes that opportunistically expand during immunodeficiency. Immune maintenance and restoration following antiretroviral therapy will continue to be invaluable in thwarting HIV-1 associated pulmonary complications. The increased expression of IFN- $\gamma$ and the CXCR3-signaling chemokines it induces suggests that immunotherapies targeted toward these immune mediators might reduce potentially damaging inflammation in lung tissues. However, immunotherapeutic strategies designed to correct these activities represent a difficult challenge, in that there is likely a balance between the level of a component of an immune response that is providing benefit to the host and an excessive level of that response that is contributing to pathogenesis. Preclinical models of these complex processes, such as the SIV/macaque model, will be required to precisely determine the relative benefits and risks of therapeutically targeting these types of inflammatory immune responses.

\section{Acknowledgements}

We thank D. McClemens-McBride, M. O'Malley, S. Ritchea, and Drs. M. Murphey-Corb and S. Capuano III of the University of Pittsburgh Primate Facility for Infectious Disease Research for assistance with project coordination and care of the animals; the PittArray Facility at the University of Pittsburgh for assistance with the macaque microarray; Dr. E. Klein for assistance with the pathological reviews; Dr. C. Balaban for advice and assistance with transcardial perfusion; and M. Delp, B. Mlechick, K. Whelton, and M. Pfeifer for technical assistance. We were kindly provided plasmids directly from Drs. K. Norris and F. Villinger. The following reagents were obtained through the AIDS Research and Reference Reagent Program, NIH: plasmids containing macaque CCR5 and CXCR4 cDNAs from Dr. P. Marx, and plasmid containing SIVmac239 provirus from Dr. R. Desrosiers. This work was supported by PHS grants HL62056 to T.A.R. and HL072682 to D.E.K.

\section{References}

[1] M.S. Dunnill, Postnatal growth of the lung, Thorax 17 (1967) 329-333.

[2] K.A. Jellinger, U. Setinek, M. Drlicek, G. Bohm, A. Steurer, F. Lintner, Neuropathology and general autopsy findings in AIDS during the last 15 years, Acta Neuropathol. (Berl) 100 (2000) 213-220.

[3] R.F. Miller, D.M. Mitchell, AIDS and the lung: update 1995. 1. Pneumocystis carinii pneumonia, Thorax 50 (1995) 191-200.

[4] J.C. Weissler, A.R. Mootz, Pulmonary disease in AIDS patients, Am. J. Med. Sci. 300 (1990) 330-343. 
[5] G.B. Baskin, M. Murphey-Corb, L.N. Martin, K.F. Soike, F.S. Hu, D. Kuebler, Lentivirus-induced pulmonary lesions in rhesus monkeys (Macaca mulatta) infected with simian immunodeficiency virus, Vet. Pathol. 28 (1991) 506-513.

[6] J.L. Mankowski, D.L. Carter, J.P. Spelman, M.L. Nealen, K.R. Maughan, L.M. Kirstein, P.J. Didier, R.J. Adams, M. Murphey-Corb, M.C. Zink, Pathogenesis of simian immunodeficiency virus pneumonia: an immunopathological response to virus, Am. J. Pathol. 153 (1998) 1123-1130.

[7] C.L. Fuller, Y.K. Choi, B.A. Fallert, S. Capuano III, P. Rajakumar, M. Murphey-Corb, T.A. Reinhart, Restricted SIV replication in rhesus macaque lung tissues during the acute phase of infection, Am. J. Pathol. 161 (2002) 969-978.

[8] T.A. Reinhart, M.J. Rogan, D. Huddleston, D.M. Rausch, L.E. Eiden, A.T. Haase, Simian immunodeficiency virus burden in tissues and cellular compartments during clinical latency and AIDS, J. Infect. Dis. 176 (1997) 1198-1208.

[9] A. Baskerville, A.B. Dowsett, R.W. Cook, M.J. Dennis, M.P. Cranage, P.J. Greenaway, Pneumocystis carinii pneumonia in simian immunodeficiency virus infection: immunohistological and scanning and transmission electron microscopical studies, J. Pathol. 164 (1991) 175-184.

[10] D.A. Croix, K. Board, S. Capuano III, M. Murphey-Corb, C.G. Haidaris, J.L. Flynn, T. Reinhart, K.A. Norris, Alterations in T lymphocyte profiles of bronchoalveolar lavage fluid from SIV- and Pneumocystis cariniicoinfected rhesus macaques, AIDS Res. Hum. Retroviruses 18 (2002) 391-401.

[11] T.A. Reinhart, B.A. Fallert, M.E. Pfeifer, S. Sanghavi, S. Capuano III, P. Rajakumar, M. Murphey-Corb, R. Day, C.L. Fuller, T.M. Schaefer, Increased expression of the inflammatory chemokine CXC chemokine ligand 9/monokine induced by interferon-gamma in lymphoid tissues of rhesus macaques during simian immunodeficiency virus infection and acquired immunodeficiency syndrome, Blood 99 (2002) 3119-3128.

[12] M.K. Kerr, G.A. Churchill, Experimental design for gene expression microarrays, Biostatistics 2 (2001) 183-201.

[13] S.K. Sanghavi, T.A. Reinhart, Increased expression of TLR3 in lymph nodes during simian immunodeficiency virus infection: implications for inflammation and immunodeficiency, J. Immunol. 175 (2005) 53145323.

[14] ABI Prism 7700 Sequence Detection System: relative quantitation of gene expression, 1997. pp. 1-36.

[15] I. Durand-Joly, A.E. Wakefield, R.J. Palmer, C.M. Denis, C. Creusy, L. Fleurisse, I. Ricard, J.P. Gut, E. Dei-Cas, Ultrastructural and molecular characterization of Pneumocystis carinii isolated from a rhesus monkey (Macaca mulatta), Med. Mycol. 38 (2000) 61-72.

[16] A.D. Luster, J.V. Ravetch, Biochemical characterization of a gamma interferon-inducible cytokine (IP-10), J. Exp. Med. 166 (1987) 10841097.

[17] J.M. Farber, Mig and IP-10: CXC chemokines that target lymphocytes, J. Leukoc. Biol. 61 (1997) 246-257.

[18] A. Iwasaki, R. Medzhitov, Toll-like receptor control of the adaptive immune responses, Nat. Immunol. 5 (2004) 987-995.

[19] E. Stylianou, P. Aukrust, K. Bendtzen, F. Muller, S.S. Froland, Interferons and interferon (IFN)-inducible protein 10 during highly active anti-retroviral therapy (HAART) - possible immunosuppressive role of IFN-alpha in HIV infection, Clin. Exp. Immunol. 119 (2000) 479-485.

[20] A. Cheret, G.R. Le, P. Caufour, O. Neildez, F. Matheux, F. Theodoro, B. Vaslin, D. Dormont, RANTES, IFN-gamma, CCR1, and CCR5 mRNA expression in peripheral blood, lymph node, and bronchoalveolar lavage mononuclear cells during primary simian immunodeficiency virus infection of macaques, Virology 255 (1999) 285-293.

[21] V.G. Sasseville, M.M. Smith, C.R. Mackay, D.R. Pauley, K.G. Mansfield, D.J. Ringler, A.A. Lackner, Chemokine expression in simian immunodeficiency virus-induced AIDS encephalitis, Am. J. Pathol. 149 (1996) 1459-1467.

[22] S. Buch, Y. Sui, N. Dhillon, R. Potula, C. Zien, D. Pinson, S. Li, S. Dhillon, B. Nicolay, A. Sidelnik, C. Li, T. Villinger, K. Bisarriya, O. Narayan, Investigations on four host response factors whose expression is enhanced in X4 SHIV encephalitis, J. Neuroimmunol. 157 (2004) 71-80.

[23] A. Cheret, G.R. Le, P. Caufour, O. Neildez, F. Matheux, F. Theodoro, F. Boussin, B. Vaslin, D. Dormont, Chemoattractant factors (IP-10, MIP-1alpha, IL-16) mRNA expression in mononuclear cells from different tissues during acute SIVmac251 infection of macaques, J. Med. Primatol. 26 (1997) 19-26.

[24] Y. Sui, S. Li, D. Pinson, I. Adany, Z. Li, F. Villinger, O. Narayan, S. Buch, Simian human immunodeficiency virus-associated pneumonia correlates with increased expression of MCP-1, CXCL10, and viral RNA in the lungs of rhesus macaques, Am. J. Pathol. 166 (2005) 355-365.

[25] R. Bonecchi, G. Bianchi, P.P. Bordignon, D. D’Ambrosio, R. Lang, A. Borsatti, S. Sozzani, P. Allavena, P.A. Gray, A. Mantovani, F. Sinigaglia, Differential expression of chemokine receptors and chemotactic responsiveness of type $1 \mathrm{~T}$ helper cells (Th1s) and Th2s, J. Exp. Med. 187 (1998) 129-134.

[26] L.J. Picker, S.I. Hagen, R. Lum, E.F. Reed-Inderbitzin, L.M. Daly, A.W. Sylwester, J.M. Walker, D.C. Siess, M. Piatak Jr., C. Wang, D.B. Allison, V.C. Maino, J.D. Lifson, T. Kodama, M.K. Axthelm, Insufficient production and tissue delivery of CD4+ memory $\mathrm{T}$ cells in rapidly progressive simian immunodeficiency virus infection, J. Exp. Med. 200 (2004) 1299-1314.

[27] F. Sallusto, D. Lenig, C.R. Mackay, A. Lanzavecchia, Flexible programs of chemokine receptor expression on human polarized T helper 1 and 2 lymphocytes, J. Exp. Med. 187 (1998) 875-883.

[28] E.S. Roberts, M.A. Zandonatti, D.D. Watry, L.J. Madden, S.J. Henriksen, M.A. Taffe, H.S. Fox, Induction of pathogenic sets of genes in macrophages and neurons in NeuroAIDS, Am. J. Pathol. 162 (2003) 2041-2057.

[29] S.A. Barber, D.S. Herbst, B.T. Bullock, L. Gama, J.E. Clements, Innate immune responses and control of acute simian immunodeficiency virus replication in the central nervous system, J. Neurovirol. 10 (Suppl. 1) (2004) 15-20.

[30] K. Abel, M.J. Alegria-Hartman, K. Rothaeusler, M. Marthas, C.J. Miller, The relationship between simian immunodeficiency virus RNA levels and the mRNA levels of alpha/beta interferons (IFN-alpha/beta) and IFN-alpha/beta-inducible $\mathrm{Mx}$ in lymphoid tissues of rhesus macaques during acute and chronic infection, J. Virol. 76 (2002) 8433-8445. 